spend their summers in quiet study. Courses of lectures are given in various subjects, one of which is natural history, and the students can, if they choose, supplement their course by laboratory study. It is exceedingly elementary, and none but begrinners attend.

Of a similar character, but of more importance, was the Sumner School of Natural History at Salem, Mass., under the direction of Prof. E. S. Morse. The principle upon which this school started was wrong. The originators secmed to have the idea that courses of lectures were esscntial to the success of the school. Such lectures, if delivered by men of reputation, were costly, and to meet the expenses of the school a large attendance was necessary. But in America the sciences arc not studied by a sufficient number of people to supply such a school, dealing in a limited branch of science, with enough students to defray the cost of lectures ; and few students can afford to pay large tuition fees. So it was that the Salem School had to depend entirely upon outside aid for its continuance, and this being withdrawn, the school was obliged to break up a few years ago. It is, indeed, unfortunate that it was obliged to do this, because it was filling an important place in American scientific education by originating an interest in teachers of the public schools for this branch of study, and thus raising the standard of scientific teaching in the lower schools. If a regular fund could be placed at the disposal of some body of scientific men for the purpose of giving instruction to teachers in this way, it would be an important thing; but unless such regular support be cstablished, other less expensive means of instruction in natural history for beginners must be looked to.

At Annisquam there is another laboratory, under the direction of Prof. Alpheus Hyatt, which has an entirely different plan for teaching beginners. At this laboratory both beginners and advanced students are allowed to study upon paying a merely nominal sum. No special instruction is given, but there is an instructor, Prof. J. B. Van Vleck, who helps the beginner over hard places in his studies. The student is given some animal to make a study of, and he is advised to examine it critically, dissect it, and makc drawings of the parts, all without the aid of a book; and then, having found out all he can without aid, he is given some book to verify his observations. In this way the student goes through all the important groups of marine invertebrate animals, often learning for the first time that he can really see things for himself without the aid of books. The powers of observation are brought into play, and the first foundation of a successful student of Nature are thus laid. How much practical benefit this method of instruction will have in making original investigators cannot be told at present, because the school has been in operation for such a short time. The amount of knowledge possessed by the students at the end of the summer, compared with that with which they started, is certainly encouraging. That this is the proper method of teaching natural history has been satisfactorily demonstrated to those in charge by the results. Both sexes are admitted, and preference is given to thosc who are going to make use of the facts which they learn, either in teaching or in special investigation. The building is a plain one-story-and-a-half house, situated at the water's edge. It is well lighted and firm, and aquaria on each table are furnished with water from a tank filled by a windmill. For collecting purposes there are common boats, and Prof. Hyatt has a schooner yacht, in which he frequently takes parties from the laboratory upon dredging expeditions. Fifteen was the average number of students last summer, and they came from all parts of the country, being mostly teachers in small colleges and schools, and a few medical students and special investigators. In its inception it was intended for beginners, but advanced students are welcomed and given the best tables. The one unfortunate thing about this laboratory is that it is not established on a firm money basis, depending each year upon a grant of money from the Woman's Educational Society of Boston, which each year, so far, has generously given the funds for its maintenance. Neither the director nor the instructor receive salaries for their work, but furnish their summers free to the cause. For the purpose of making collections there is no better place on the eastern coast of the United States, with the exception, perhaps, of Eastport, Maine. The variety of animals is immense, and their abundance is also great, every condition necessary to an extensive fauna being present.

The last laboratory which we shall notice is the one which has long since passed out of active existence, in fact which died with its founder, the elder Agassiz. It was an immense building of wood on the island of Penikese, in Massachusetts, the outermost of the chain known as the Elizabeth Islands. The location was poorly chosen, for the fauna in the vicinity is poor, and there was no regular communication with the mainland, which was twenty miles distant. At one time during its brief existence it had a very large attendance, beginners particularly being attracted by the name of the eminent director. Lectures were given and laboratory practice was allowed each student. At this school such men as Fewkes, Faxon, Brooks, Whitman, and Alexander Agassiz, who have since become eminent in American science, received some of their first instruction in natural history. The death of Agassiz ended the institution, which if it could have been kept up under his direction would no doubt have equalled if not excelled any similar institution in the world. It is doubtful if even under Agassiz's direction this stupendous school could have been carried on, for we understand that the money basis was very insecure, and certainly the expenses were very heavy, and the tuition charges light.

RALPH S. TARR

\section{ON A NEW METHOD FOR THE TEACHING OF SCIENCE IN PUBLIC ELEMENTARY SCHOOLS ${ }^{1}$}

THE desirability of imparting to children some knowledge of the principles of science is now so generally agreed upon that this paper will be devoted not to the argument that science-teaching is necessary, but to a description of a method by which it may be successfully and thoroughly carried out.

In the "Code" under which the system of Government education is carried on in this country, science is mentioned under two heads :-

(I) As a "class-subject" (optional) which may be taught to any or all of the seven "Standards" under which the children are classed, and

(2) As a "specific subject" (also optional) which may only be taken by the children in Standards V., VI., and VII. The specific subjects named are-

I. Algebra.

2. Euclid and Mensuration.

3. Mechanics.

4. Latin.

5. French.

6. Animal Physiology.

7. Botany.

8. Principl s of Agriculture.

9. Chemistry.

Io. Sound, Light, and Heat.

I1. Magnetism and Electricity.

I2. Domestic Economy (Girls).

Either one or two (but not more than two) of these specific subjects may be taken by a child. The course in each subject is divided into three parts, so that a child must remain at school for three years in order to complete the study of any one subject.

The grants paid are at the rate of is. for a "fair" or $2 s$. for a "good" pass in class-subjects, and 4 s. per pass in the specific subjects.

I By W. Jerome Harrion, F.G.S., Science Demonstrator for the Birmingham School Buard. The greater portion of this article was read as a communication to the International Conference on Education, held at the Health Exhibition in July last, and is here reprinted by permission of the Executive Council. 
To be succcssful in a public elementary school any scheme of instruction must be based upon the conditions of the Code. To these conditions, as they now stand, the following exceptions may be taken :--

(a) The teacher is forced to choose between geography and science as a class-subject. He may take either, but he cannot take both. As a rule he takes geography. It is to be hoped that in the future thi; restriction may be removed, and that a simple course of object-lessons on plants, animals, manufactures, \&c., which would fulfil the requirements of science as a class-subject, will be given in addition to those lessons on geography which are really indispensable.

(b) The three years' course in a specific subject is too long, now that the child does not begin the study until it enters the Fifth Standard. Taking the case of the boys and girls presented for examination during 1883 in the Birmingham Board schools, we find in Standard V. 1864 children ; in Standard VI. 482 ; in Standard VII. 85.

Tracing back the eighty-five Seventh Standard children, we find that they are the residue of 427 Sixth Standard children of 1882, and of I 223 who passed the Fifth Standard in I881. It would probably be better to reduce each specific subject to a two years' course, and to allow Seventh Standard children to be examined in the work of the two previous years.

CHOtce of SUbJEcTs.-In considering what science

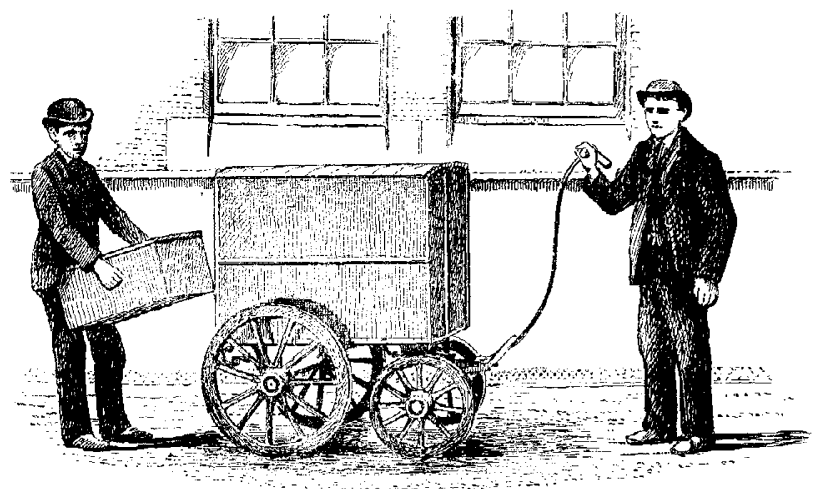

F1G. r.-Hand-cart used for conveying apparatus from school to school.

subjects to select from those named in the Code, much will depend upon local conditions. Generally speaking, for boys' schools mechanics should be chosen, and for girls' domestic economy. As a second subject in town schools, either chemistry or magnetism and electricity may be recommended for boys, and animal physiology for girls. In country schools, principles of agriculture for boys, and botany for girls, will be found very suitable.

In the new Seventh Standard School, lately opened by the Birmingham School Board, there is an excellent workshop, fitted up with carpenters' benches, forge, lathe, \&c., for forty boys. For this school I have drawn up a syllabus of a (proposed) new specific subject, entitled "Principles of Tools and Propertics of Materials."

OBJECTIONS TO SCIENCE-TEACHING.-In time past three principal objections have been urged to the introduction of science-teaching into public elementary schools. These objections are:-

(r) Want of Qualified Teachers.-The ordinary teachers and pupil-teachers of our schools have not, as a rule, the sound knowledge of principles and practised powers of manipulation which are necessary in order to teach science with power and effect.

(2) Want of Time.-To prepare for a science-lesson, and to properly clean and put azvay the apparatus, requires more time than our closely-worked schoolteachers are able to give. Some have also urged that "time" cannot be spared from the study of the "three R's," in which they consider incessant mechanical practice to be necessary.

(3) Cost of Apparatus.--To teach science practicallyand it should be so taught to be of any value-a considerable sum must be spent in the purchase of apparatus. Thus the apparatus required for the three stages of mechanics costs about $75 \%$, and for domestic economy 65l., and this is a considerable expenditure for a single school.

The ITINERANT MeTHOD OF SCIENCF-TEACHING.A method by which the principal objections urged against science-teaching in elementary schools may be overcome was suggested a few years ago by Col. Donnelly and Prof. Huxley, and it is not the least of the many services which these gentlemen have rendered to science and to education. This method has been carried out on a large scale, and with the most gratifying success by the School Boards of Birmingham and Liverpool, and the object of the present paper is to describe the manner in which the work is done in the former town.

The principal features of the itinerant method of science-teaching are as follows :--

(I) A science demonstrator is appointed, who should combine a practical knowledge of school-work and power to teach large classes with a thorough acquaintance with the branches of science which he is to teach.

(2) A "centre" is chosen in connection with some particular school, where a class-room may be set apart, or (better) a subsidiary building erected, where apparatus can be kept and the experiments prepared.

(3) A hand-cart must be provided (Fig. I), into which the boxes containing the apparatus fit, and can so be conveyed from the science-centre to school after school by a strong youth. In this way one set of apparatus will serve for many schools. In each school department there must be a trestle-table, which should be placed in front of the class as the time for the science-lesson draws near. The hand-cart is brought to the school, the youth carries in the boxes, unpacks the apparatus, and places it upon the table. Then the science demonstrator walks in and gives the lesson. Afterwards the youth packs up the apparatus in the boxes, replaces them in the handcart, and marches off to the next school.

(4) A time-table is drawn up showing the exact time at which the science-lesson is given at each school, and its duration (forty-five minutes will be found suitable). A syllabus of each year's course of lessons must also be prepared (which should be distributed to the classteachers and children), so that the subject may be gone through in a systematic way. As a rule it will be found possiblc for each science demonstrator to give four lessons per day, or twenty per week.

Fach class should receive a lesson from the demonstrator at least once a fortnight. At each science-lesson the ordinary teacher of the class is present, and takes full notes of the matter given. During the intervening week the class-teacher recapitulates the science-Jesson, giving such additional or new illustrations as he or she may be able to provide. The children then either write a general account of the lesson or answer three or four questions upon it, and the papers worked are submitted to the science demonstrator when he next visits the class.

It is plain that the itinerant system fairly meets the objections which have been urged against the introduction of science-teaching on the grounds of want of qualified teachers, want of time, and cost of apparatus. It also secures systematic and continuous teaching throughout the school year. The teaching is practical, and every fact or law is demonstrated experimentally. Wherever eight or ten schools are within a reasonable distance of each other, this plan may be carried into effect. Voluntary schools may combine with Board schools (as is done in Liverpool) to secure the services of a science demonstra- 
tor, or small towns near to one another (as in Lancashire and Yorkshire, or in the Black Country), may unite for the same end.

ApPlication of the Itinerant System of ScienceTEACHING IN Birmingham.-It was in June I880 that $I$ received my present appointment from the Birmingham School Board. Since that time the work in which $I$ have been engaged has received the unanimous approval of the Board, but I ought especially to acknowledge the encouragement received from the Chairman-Mr. George Dixon-and from Dr. Crosskey, and the valuable advice given by the able and experienced Clerk to the Board, Mr. G. B. Davis.

Three assistants have been appointed, with a junior laboratory assistant, and two youths who work the two hand-carts which we now employ. The regular science staff thus includes seven individuals, whose salaries amount to $750 l$. per annum. In connection with the new Icknield Street School an admirable laboratory has been erected, at a cost (with fittings) of $1450 \mathrm{l}$., including a lecture theatre to seat eighty, a chemical laboratory and store-room, and a demonstrator's room (Fig. 2). About $400 l$. has been expended in the purchase of apparatus.

There are now thirty schools under the Birmingham School Board, attended by nearly 40,000 children.

In each of the thirty boys' departments $\mathrm{Me}$ chanics is taken as a specific subject by every boy in the Fifth and higher Standards; six departments take magnetism and electricity as a second specific subject.

In each of the thirty girls' departments Domestic Economy is taken as a specific subject by every girl in the Fifth and higher Standards; three departments take animal physiology as a second specific subject.

At the request of the teachers a few Fourth Standard children of exceptional ability are allowed to attend the science-lessons, since it is found not merely to do them good mentally but to induce them to remain longer at school.

The total number of children now receiving instruction in science in the Birmingham Board schools is, in round numbers :-

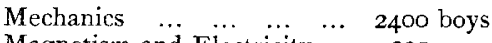

$$
\begin{aligned}
& \text { Magnetism and Electricity ... } 300 \text {,, } \\
& \begin{array}{llll}
\text { Domestic Economy } & \ldots & \ldots & \text { I } 800 \text { girls }
\end{array} \\
& \text { Animal Physiology ... ... } 100 \text {," }
\end{aligned}
$$

In the framing of the syllabuses a wide interpretation has been given to these subjects; thus under the head of domestic economy as much elementary chemistry and physiology are taught as will enable an intelligent girl to comprehend the familiar facts of home life.

As a rule two science-teachers and two youths go with each hand-cart, so that the lessons to boys and girls go on simultaneously in each school. By this plan each hand-cart can visit four schools (eight departments) daily, while with a single teacher only two schools (four departinents) could be visited.

The same lesson is given to class after class throughout the week. It is previously very carefully prepared by the science-demonstrator, is written out in full by him, and the experiments are tried over and the apparatus packed on Saturday morning, so that everything is ready for the start on Monday morning.

In each science subject there is but one stage taught in each school. Children entering on the subject join in at the second or third stage, as the case may be, so that all the children in any one department form one class, working at the same stage of the same subject. This plan

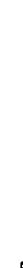

simplifies the work wonderfully, and it is found in practice that the science subjects taken may be as conveniently commenced at any one of the three stages into which each is divided in the Code as at any other. Each stage stands quite by itself, and each may be considered in turn as forming an introduction to the other two.

RESUltS OF THE SCIENCE-TEACHING IN BIRMINGHAM. - The visits of the science demonstrator have been welcomed both by the teachers and children of the Board schools. The teachers have earnestly co-operated in the
(2)
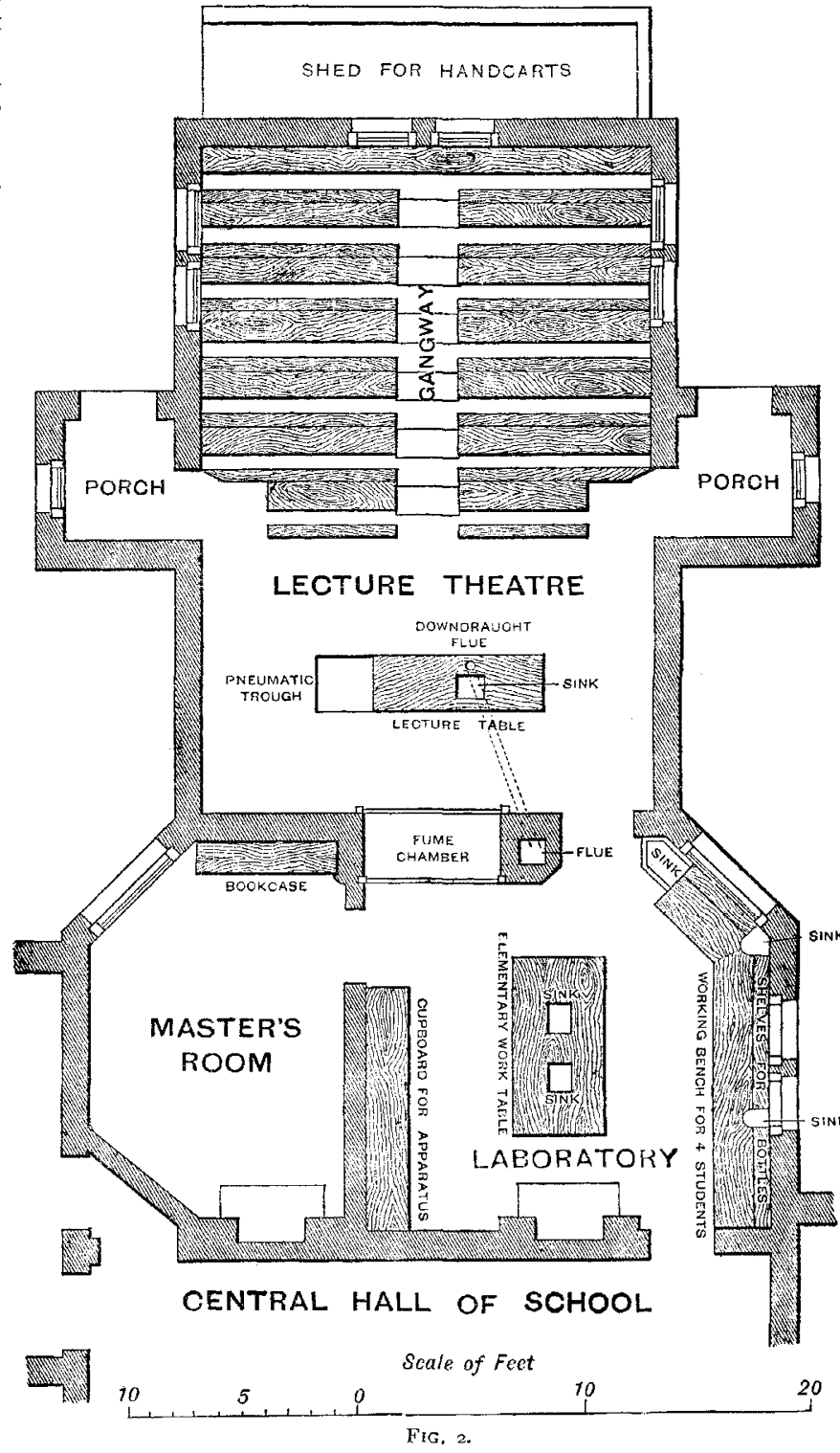

work, and much of its success is due to their efforts. With the children, the science-lessons have proved extremely popular. There is invariably a good attendance on the day of the science-lesson. Among the boys the halftimers then muster strongly, often getting leave to come in for that lesson only, and sitting with bare arms and rolledup aprons, just as they have run from their work. In the same way big girls, who cannot escape from tyrannical babies, beg leave to bring their charges into the classroom; and I know of many a case where "mother" has been persuaded to change her "washing-day" because it 
clashed with the day of the demonstrator's lesson in domestic economy. The teaching has evidently been carried home, for an iratc landlord visited one school to "know what they meant by teaching children that his houses were not fit to live in!" the said houses being built "back to back," a practice the evils of which are pointed out in one of our domestic economy lessons. The large number of papers, essays, mechanical drawings, models of apparatus, \&c., exhibited by the Birmingham School Board at the Health Exhibition will give some idea of the results of the work and of the eager manner in which it has been taken up by the children. So far from the science-lessons having interfercd (by taking up time which would otherwise have been spent on the three R's) with the ordinary school work, the unanimous testimony of the teachers is that the increased intelligence of the children enables them to do their Standard work more easily. The idea has been very prevalent that by incessant mechanical practice excellence in the "three R's" can be secured; but the fact is that unless the intelligence be cultivated, no subject can be properly learnt. True education is culture of the mind, and mechanical acquirements have nothing in common with culture.

Applying to the matter the practical test of the Government examinations by Her Majesty's inspector, the result s come out in a very satisfactory way.

\begin{tabular}{|c|c|c|c|c|c|c|}
\hline \multirow{2}{*}{$\begin{array}{l}\text { Yeat } \\
\text { I } 878\end{array}$} & \multicolumn{4}{|c|}{$\begin{array}{c}\text { Number of passes } \\
\text { in specific } \\
\text { subjects }\end{array}$} & \multicolumn{2}{|c|}{$\begin{array}{l}\text { Percentage of } \\
\text { passes in the } \\
\text { three R's }\end{array}$} \\
\hline & $\cdots$ & $\cdots$ & I 2 I & $\cdots$ & ... & $81 \cdot 3$ \\
\hline 1879 & $\ldots$ & $\ldots$ & 424 & .. & $\ldots$ & 82.0 \\
\hline $1880^{1}$ & $\ldots$ & $\cdots$ & $8_{4} \mathrm{I}$ & $\ldots$ & $\cdots$ & $8_{4} \cdot 7$ \\
\hline I 88I & $\cdots$ & $\ldots$ & I 724 & $\ldots$ & $\ldots$ & $88 \cdot 4$ \\
\hline 1882 & .. & $\ldots$ & 3 I I 4 & $\ldots$ & $\ldots$ & $92 \cdot 6$ \\
\hline I $883^{2}$ & $\ldots$ & $\ldots$ & 3150 & $\ldots$ & $\ldots$ & $80 \cdot 6$ \\
\hline
\end{tabular}

Another plcasing fact is the much larger number of children now found in the upper Standards. In 1879 (the year before the introduction of science-teaching) the percentagc of children examined in Standards IV. to VII. was only $19^{\circ} 5$; it is now 337 .

The following extracts from the published reports of the Birmingham School Board prove that, in the estimation of those best able to judgc, the teaching of science has proved a success.

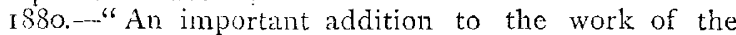
Board schools has been the introduction of experimental lessons in elementary science. A science demonstrator has been appointed, and has now commenced work."

$188 \mathrm{r}$.- "In June I $88 \mathrm{I}$ the Board decided to appoint an assistant science demonstrator. The lessons in elementary science had proved so successful and attractive, that it was folt to be unfair that such advantages should be denied to some schools while they wcre afforded to others."

"These science-lessons are fully answering our expectations; the children are very attentive and much interested in the work; and, in addition to the useful knowledge they gain, their gencral intelligence is being developed."

1882.- "The succcss of the science-teaching has been strongly marked, both by the papers worked by the candidates for the science scholarships, and by the greater development of intelligence shown in regard to other subjects."

"As the teaching of science in board schools has now become cxccedingly popular, and many of the children have made considerable progress, six scholarships of Iol. each have becn founded in connection with the Science and Art Department."

"Upwards of one thousand boys are now receiving admirable lessons in elemcntary science in the Board

I Science demonstrator appointed June 1880

Mundella Code introduced, by which Literature (in which 1435 passes were made in preceding year) was romoved from list of specific subjects the general requite nents of this Code being higher, there wa; a slight dron in the pe:centage of passes for this year. schools, and the result of this teaching is little less than marvellous."

I883. - "The teaching of elementary science in the Board schools has developed considerably during the year, the scholars taking great interest in it, and the results shown by the cxaminations being such as to prove that the knowledge imparted has been largely retained."

"Two great steps in advance have been made by the present Board. One is the establishment of science classes. The remarkable success which has attended these classes has becn frequently alluded to, and is generally known."

Science Scholarships.-Twelve science scholarships of Iol. per annum have now been established in connection with the Science and Art Department. The boys who obtain these scholarships, together with an equal number. sclected as showing special aptitude for science, spend each Fridlay afternoon at the science laboratory in the study of analytical chemistry. All those hitherto examincd have passed (and a large number in the first class) at the May examinations of the Department.

There are also two valuable science scholarships by which boys may pass from the Board schools to King Edward's Grammar School, and thence to the Mason Science College, their parents mcanwhile receiving allowances of $15 \%$ and $25 \%$ per annum for their support. These scholarships are very keenly competed for, the usual number of boys examined being over zoo. The examiner, Prof. Poynting, M.A., of Mason College, reports as follows :-

I 882. - "Hardly any of the questions in my paper could have been answered without independent thought on the part of the canclidates, and I had but very few answers showing a want of such thought. The boys showed that they had seen and understood the experiments which they described, that they had becn taught to reason for themselves upon them, and that they were not merely using. forms of words which they had lcarnt, without attaching physical ideas to them."

I883.- "The paper worked by the boy who stands highest on the list was an excellent one, and showed considerable power. The next five boys also deserve special mention as having done very good wor's. I think the general style of work sent in was very satisfactory. The average was not so high as last year, as the third stage of the subject was far more difficult, and the paper set was also much harder, but I think that quite as much ability was shown on the part of the candidates, and that the evidence of careful teaching was quite as strong."

Mr. Richard Tangye-the head of the great firm of Tangye and Co.- has taken a warm personal interest in the work, and his aid and countenance have been most valuable. He testifies strongly to the great improvement of his young "hands" since the introduction of the School Board system in Birmingham.

Summing up the matter, the results which we hope to obtain from this science-teaching, and which indeed have already manifested themselves, are:-

(I) The general quickening of the intellectual life of the school.

(2) The imparting of scientific knowledge and method to children which will be useful to them in after life, and which will cause many of them to continue their sciencestudies in cvening classes. ${ }^{1}$

(3) The discovery of children of exceptional ability, and their support by means of scholarships.

(4) The instruction of the school-teachers in scientific principles, which they may apply to the general work of the school.

Evening Work in Science.-The work done among the teachers by means of cvening science classes in connec-

1 The last Report of the Birmingham and Midland Institute speaks of the intlux of youtlis into the evening science clasiss-" the result doubtless of the science-teaching now carried on in the Board schools." 
tion with the Science and Art Department has been of an important character. The Birmingham School Board employs about 800 teachers, and it now provides education, by means of training classes, for about 450 (the pupil-teachers and uncertificated assistants). The growth of the science work in this direction will appear from the following table :-

\begin{tabular}{|c|c|c|c|c|c|c|}
\hline \multicolumn{2}{|l|}{ Year } & $\begin{array}{l}\text { Number of } \\
\text { Certificates } \\
\text { obtained }\end{array}$ & \multicolumn{3}{|c|}{$\begin{array}{l}\text { Number of } \\
\text { First Class Certi- } \\
\text { ficates awarded }\end{array}$} & Gross Grant \\
\hline I 88 I & $\ldots$ & 24 & $\ldots$ & 0 & $\ldots$ & tis \\
\hline 188 & $\ldots$ & $9 \mathbf{I}$ & $\ldots$ & 18 & $\ldots$ & $\widehat{E} 108$ \\
\hline & $\ldots$ & 100 & $\ldots$ & 24 & $\ldots$ & EI 24 \\
\hline 188 & $\ldots$ & 173 & $\ldots$ & 33 & $\ldots$ & f197 \\
\hline
\end{tabular}

It is very important to elementary school teachers to do well in science, since (by a regulation of the Education Department) those who have passed in science have a certain number of marks added to those which they obtain for other subjects at the Queen's Scholarship and Certificate Examinations, through which all these teachers have subsequently to pass.

Electricity and magnetism has been taught to the pupilteachers, and physiography to the assistants.

When evening science lectures are given, however, no school-work can be done by the demonstrators in the afternoon of the same day, as the time is taken up with the preparation of the experiments, \&c., for the evening lectures.

The Board possesses an excellent optical lantern presented by Messrs. R. and G. Tangye as a token of their appreciation of the science-teaching and with its assistance the science demonstrator gives popular evening science lectures in the various schools, taking subjects such as will be likely to awaken the interest and increase the intelligence of the children, as "Wild Animals in the Zoo," "The Star-lit Sky," "Two Days in London," "A Voyage to the Moon," \&c. Occasionally, on fine evenings, the elder children are shown the moon, planets, doublestars, \&c., through a three-inch achromatic telescope (refractor). These expositions tend to attract children to school, and to improve the regularity of the attendance.

CoST OF THE SySTEM.--The following rough balancesheet for the year $1883^{-34}$ shows the very small cost at which the work of science-teaching is carried on in Birmingham :-

Receipts.

Half of Government Grant on specific subjects $f_{f}$ s. $d$.

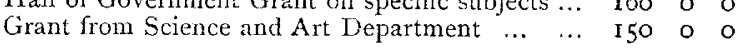

\section{Expenditune.
Salarics ...}

$\begin{array}{lllllllllllll}\text { Salarics } & \ldots & \ldots & \ldots & \ldots & \ldots & \ldots & \ldots & \ldots & \ldots & 750 & 0 & 0\end{array}$

... 70 o 00

Renewal of apparatus and cost of materials $\cdots \frac{50}{580}$

Net cost to the Board ... $\ldots . \& 560$ per annum.

As a penny rate yields 6000 ., it will be seen that the cost of this system, by which more than 4000 children, distributed over sixty school departments, receive regular and practical science-lessons, amounts to only one-tenth of a penny in the pound, or to $g l$. ros, per annum for each school department. It must be remembered also that the full benefit of the system has not yet been reaped, and that the grants will certainly continue to increase. Credit has only been taken for one-half of the grant for the specific subjects.

TEXT-Books.-Failing to meet with works exactly suitable for the wants of the children, the science-lessons in mechanics and in domestic economy have been written out in full, and are now published by Messrs. T. Nelson and Sons. Similar works on magnetism and electricity and on chemistry are nearly ready for issuc. Each work consists of three small volumes corresponding with the three years' course prescribed by the Code. These books have already been adopted by the School Board for London, the Irish Intermediate Education Board, and other important educational bodies.

SCHOOL MUSEUMS.-For use in object-lessons, and as a constant source of pleasure and instruction, a small collection of typical objects stored in a glass-fronted cupboard ought to be placed in every school. Such cupboards are now being supplied to the Birmingham Board schools, and it has naturally fallen to the lot of the science demonstrator and his staff to assist in the mounting, naming, and classification of the objects with which the cupboards are, at little or no expense to the Board, to be filled.

CONCLUSION.--Since the commencement of this system of practical instruction in science in Birmingham, many eminent men have visited the schools to see it in operation, and they have been unanimous in their approval. In the "Instructions to Inspectors" issued by the Education Department, the system receives official sanction and commendation:- "You will often find that these (specific) subjects are most thoroughly taught when a special teacher is engaged by a group of schools to give instruction in such subjects once or twice a week, his teaching being supplemented in the intervals by the teachers of the school."

The Commissioners for Technical Education visited the Icknield Street Centre a few months ago, heard sciencelessons given, and cxamined fully into the work. In their valuable Report, recently issued, they say:- "We could hardly overstate our appreciation of the value of the plan of giving instruction in natural science by special teachers as carried out in the Board schools of Liverpool and Birmingham, where the employment of a well-qualified science demonstrator insures the sound character of the instruction, whilst the repetition of the lesson by the schoolmaster enables him to improve himself in the methods of science-teaching."

Within the present year the work has been crowned by the opening of a Technical School for Seventh Standard boys, situated in the centre of the town, and fitted with an admirable laboratory (for forty boys), lecture-theatre, workshop (for forty, with three lathes), room for drawing, class-rooms for the ordinary subjects, and a capital dining-hall, \&c. The building has been adapted, fitted (at a cost exceeding $2000 \mathrm{l}$.), and presented rent-free to the Board by Mr. George Dixon. This school will constitute the last link of the chain of elementary education supported by the town, and who can doubt that in it will be laid the foundation of many a good work, both for the individual and the community.

\section{NOTES}

Mr. J. J. Thomson has been elected to fill the post of Cavendish I'rofessor of Experimental Physics in the University of Cambridge in succession to Lord Rayleigh. A numerously signed requisition to $\mathrm{Sir} \mathrm{Wm}$. Thomson to become a candidate was declined.

CAMBridge was $e^{n}$ fêle on Monday. Peterhouse, the oldest collegiate institution in the University, was cclebrating the six-hundredth anniversary of its foundation. It was stated at the dinner that one-third of the present Fellows were Fellows of the Royal Society.

IT is announced that the International Sanitary Conference, which Signor Mancini proposed some time ago, will meet at Rome in Fcbruary or March. Later on another Conference, also suggested by Signor Mancini, will meet to consider the possibility of some agreement for the mutual exccution by the Signatory Powers of legal judgments. 